\title{
High glucose and insulin in combination cause insulin receptor substrate-1 and -2 depletion and protein kinase $B$ desensitisation in primary cultured rat adipocytes: possible implications for insulin resistance in type 2 diabetes
}

Jonas Burén, Hui-Xia Liu, Johan Lauritz and Jan W Eriksson

Department of Medicine, Umeå University Hospital, S-901 85 Umeå, Sweden

(Correspondence should be addressed to J W Eriksson; Email: jan.eriksson@medicin.umu.se)

\begin{abstract}
Objective: The purpose of this study was to investigate the cellular effects of long-term exposure to high insulin and glucose levels on glucose transport and insulin signalling proteins.

Design and methods: Rat adipocytes were cultured for $24 \mathrm{~h}$ in different glucose concentrations with $10^{4} \mathrm{\mu U} / \mathrm{ml}$ of insulin or without insulin. After washing, ${ }^{125} \mathrm{I}$-insulin binding, basal and acutely insulin-stimulated D- $\left[{ }^{14} \mathrm{C}\right]$ glucose uptake, and insulin signalling proteins and glucose transporter 4 (GLUT4) were assessed.

Results: High glucose (15 and $25 \mathrm{mmol} / \mathrm{l})$ for $24 \mathrm{~h}$ induced a decrease in basal and insulin-stimulated glucose uptake compared with control cells incubated in low glucose $(5$ or $10 \mathrm{mmol} / \mathrm{l})$. Twenty-four hours of insulin treatment decreased insulin binding capacity by $\sim 40 \%$, and shifted the doseresponse curve for insulin's acute effect on glucose uptake 2- to 3-fold to the right. Twenty-four hours of insulin treatment reduced basal and insulin-stimulated glucose uptake only in the presence of high glucose (by $\sim 30-50 \%$ ). At high glucose, insulin receptor substrate-1 (IRS-1) expression was downregulated by $\sim 20-50 \%$, whereas IRS-2 was strongly upregulated by glucose levels of $10 \mathrm{mmol} / \mathrm{l}$ or more (by 100-400\%). Insulin treatment amplified the suppression of IRS-1 when combined with high glucose and also IRS-2 expression was almost abolished. Twenty-four hours of treatment with high glucose or insulin, alone or in combination, shifted the dose-response curve for insulin's effect to acutely phosphorylate protein kinase B (PKB) to the right. Fifteen mmol/l glucose increased GLUT4 in cellular membranes (by 140\%) compared with $5 \mathrm{mmol} / \mathrm{l}$ but this was prevented by a high insulin concentration.

Conclusions: Long-term exposure to high glucose per se decreases IRS-1 but increases IRS-2 content in rat adipocytes and it impairs glucose transport capacity. Treatment with high insulin downregulates insulin binding capacity and, when combined with high glucose, it produces a marked depletion of IRS-1 and -2 content together with an impaired sensitivity to insulin stimulation of PKB activity. These mechanisms may potentially contribute to insulin resistance in type 2 diabetes.
\end{abstract}

European Journal of Endocrinology 148 157-167

\section{Introduction}

Insulin resistance is an important component of type 2 diabetes, and hyperglycaemia as well as hyperinsulinaemia can contribute to its deterioration (1-3). Insulin levels are increased to compensate for progressing insulin resistance, but on the other hand, hyperinsulinaemia leads to a further impairment in insulin sensitivity, partly via receptor downregulation (4). In addition, hyperglycaemia may cause and promote insulin resistance in type 1 and 2 diabetes, leading to decreased glucose uptake and glucose utilisation $(1,5,6)$. The effects of hyperglycaemia may be partly mediated by metabolites of the hexosamine pathway (7) or activation of different protein kinase $C$ isoforms $(8,9)$.

Insulin binding to the insulin receptor initiates a cascade of intracellular signalling events, including receptor autophosphorylation and subsequent phosphorylation and/or activation of downstream molecules, including insulin receptor substrates (IRSs), phosphatidylinositol 3-kinase (PI3-K), protein kinase $\mathrm{B}$ (PKB) and probably other molecules of importance for activation of the glucose transport system. The final step in this signalling cascade is the translocation of glucose transporter 4 (GLUT4) from intracellular 
compartments to the plasma membrane, thereby facilitating the entry of glucose into insulin-sensitive cells like muscle and fat cells. Glucose transport is considered to be the rate-limiting step in glucose metabolism in insulin-sensitive tissues like muscle and fat under most physiological conditions $(10,11)$. Various cellular defects resulting in insulin-resistant glucose transport have been proposed, including alterations in insulin receptor function, depletion of the GLUT4 transporter pool and alterations in the post-receptor signalling pathway. We have recently shown that insulin can exert an upregulating effect on GLUT4 mRNA level in 3T3-F442A adipocytes at low $(5.6 \mathrm{mmol} / \mathrm{l})$ but not high $(25 \mathrm{mmol} / \mathrm{l})$ glucose levels (12). These data stress the importance of evaluating possible interaction effects besides the isolated effects of high levels of glucose and insulin.

In the present work we have studied the effects of high glucose and insulin, alone or in combination, on glucose transport capacity and on the cellular content of insulin signalling proteins and GLUT4. We wished to mirror four different stages in the development and progression of type 2 diabetes, namely, in their usual order of appearance: (i) the normal state with low glucose and insulin levels, (ii) the hyperinsulinaemic state, (iii) the hyperinsulinaemic and hyperglycaemic state, and finally (iv) the hyperglycaemic state alone. For this purpose we have used primary cultured rat adipocytes as an established model of target cells of insulin. Most previous work on cultured adipocytes has employed high glucose concentrations, $\sim 25 \mathrm{mmol} / \mathrm{l}$, in the culture medium, but we studied several different glucose levels, with and without a high, saturating concentration of insulin. We assessed insulin-signalling proteins and, in particular, downstream events, i.e. activation of PKB and glucose transport.

\section{Materials and methods}

\section{Animals}

Male Sprague-Dawley rats were obtained from B\&K (Sollentuna, Sweden). The Umeå Ethical Committee for Animal Research approved the study protocol.

\section{Chemicals}

DMEM, fetal calf serum (FCS), penicillin/streptomycin and Medium 199 were obtained from Gibco BRL, Life Technologies (Paisley, Strathclyde, UK). Collagenase $\mathrm{A}$ and adenosine deaminase (ADA) were from Boehringer Mannheim (Mannheim, Germany). BSA (fraction $V$ ) and $N^{6}$-(R-phenylisopropyl) adenosine (PIA) were purchased from Sigma Chemical Co. (St Louis, MO, USA). Human insulin (Actrapid) was from Novo Nordisk A/S (Copenhagen, Denmark). D-[U- $\left.{ }^{14} \mathrm{C}\right]$ glucose (specific activity $\sim 200-300 \mathrm{mCi} /$ mmol), human monocomponent $\left[{ }^{125} \mathrm{I}-t y r^{14}\right]$ insulin (specific activity $\sim 2000 \mathrm{Ci} / \mathrm{mmol}$ ) and ECL-Plus-Blotting reagents were purchased from Amersham Pharmacia Biotech, Freiburg, Germany. Anti-IRS-1, IRS-2, p $85 \alpha / \beta$ (PI3-K), Akt1/2 (PKB) and GLUT4 polyclonal antibodies as well as secondary antibodies were obtained from Santa Cruz Biotech Inc. (Santa Cruz, CA, USA). The anti-phospho-Akt1 $\left(\mathrm{Ser}^{473}\right)$ antibody was from New England Biolabs (Beverly, MA, USA).

\section{Isolation and primary culture of rat adipocytes}

Male Sprague-Dawley rats $(150-200 \mathrm{~g})$, fed freely, were killed by decapitation and epididymal fat pads were immediately excised and minced. Isolated fat cells were obtained by shaking finely minced tissue in polypropylene containers at $37^{\circ} \mathrm{C}$ for $1 \mathrm{~h}$ in Medium 199 containing $5.6 \mathrm{mmol} / \mathrm{l}$ glucose with $40 \mathrm{mg} / \mathrm{ml}$ BSA and $0.6 \mathrm{mg} / \mathrm{ml}$ collagenase. Cells were then filtered through a nylon mesh and washed four times with fresh medium. Isolated adipocytes were placed in flasks containing DMEM with $5,10,15$ or $25 \mathrm{mmol} / \mathrm{l}$ (initial concentrations) D-glucose, 10\% FCS, penicillin $(100 \mathrm{U} / \mathrm{ml})$ and streptomycin $(100 \mu \mathrm{g} / \mathrm{ml})$. The cells were incubated at $37^{\circ} \mathrm{C}$ for $24 \mathrm{~h}$ under a gas phase of $95 \% \mathrm{O}_{2}$ and $5 \% \mathrm{CO}_{2}$ in the absence or presence of insulin $\left(10^{4} \mu \mathrm{U} / \mathrm{ml}\right)$. Glucose concentrations decreased slightly after $24 \mathrm{~h}$, e.g. to $\sim 4$ and $\sim 12 \mathrm{mmol} / \mathrm{l}$ for cells cultured at initial glucose concentrations of 5 and $15 \mathrm{mmol} / \mathrm{l}$ respectively. Cell size was determined in isolated adipocytes as previously described (13) and it did not differ between the varying incubation conditions (data not shown). Cell viability was verified by trypan blue exclusion tests.

\section{Glucose uptake assay}

After $24 \mathrm{~h}$ incubation of isolated adipocytes and washing four times, glucose uptake was assessed as previously described $(14,15)$. The washing procedure will remove all insulin in the medium and it dissociates $>90 \%$ of any cell-bound insulin from the pretreatment period (16). In brief, adipocytes (lipocrit 3-5\%) were incubated at $37^{\circ} \mathrm{C}$ in Medium 199 without glucose for $15 \mathrm{~min}$ with $4 \% \mathrm{BSA}$, ADA $(1 \mathrm{U} / \mathrm{ml})$, PIA $(1 \mu \mathrm{mol} / \mathrm{l})$ and various insulin concentrations $(0-1000 \mu \mathrm{U} / \mathrm{ml})$. After that, D-[U- $\left.{ }^{14} \mathrm{C}\right]$ glucose $(0.86 \mu \mathrm{mol} / \mathrm{l})$ was added. The cells were separated from the incubation medium after $1 \mathrm{~h}$ by centrifugation through silicone oil and the radioactivity associated with the cells was measured by scintillation counting. Under these experimental conditions glucose uptake is mainly determined by the rate of transmembrane glucose transport (17). The cellular clearance of glucose from the medium was calculated according to the following formula and taken as an index of the rate of glucose uptake: cellular clearance of medium glucose $=$ (c.p.m. cells $\times$ volume) $/($ c.p.m. medium $\times$ cell number $\times$ time). 


\section{${ }^{125}$ I-insulin binding to adipocytes}

After the culture period the fat cells were washed four times and thus $>90 \%$ of any bound insulin was removed (16). Thereafter, the cells (lipocrit 5-10\%) were incubated with ADA $(1 \mathrm{U} / \mathrm{ml})$, PIA $(1 \mu \mathrm{mol} / \mathrm{l})$ and $2 \mathrm{mmol} / \mathrm{l} \mathrm{KCN}$ for $5 \mathrm{~min}$ at $37^{\circ} \mathrm{C}$ to deplete the cells of ATP and stop receptor internalisation and recycling (16). Subsequently, cell surface binding of ${ }^{125} \mathrm{I}$-insulin $(0.2 \mathrm{ng} / \mathrm{ml})$ was carried out for $60 \mathrm{~min}$ at $16^{\circ} \mathrm{C}$. After the incubation period, cells and medium were separated by centrifugation through dinonyl phthalate and ${ }^{125}$ I-insulin binding to cells was measured. Non-specific binding, defined as binding in the presence of $10^{5} \mu \mathrm{U} / \mathrm{ml}$ unlabelled insulin, was subtracted.

\section{Western analysis of total cellular lysates}

After the $24 \mathrm{~h}$ incubation period, cells were washed four times with PBS and lysed with $0.2-0.4 \mathrm{ml}$ lysis buffer $(25 \mathrm{mmol} / \mathrm{l}$ Tris-HCl, pH $7.4, \quad 0.5 \mathrm{mmol} / \mathrm{l}$ EGTA, $25 \mathrm{mmol} / \mathrm{l} \mathrm{NaCl}, 1 \%$ Nonidet P-40, $1 \mathrm{mmol} / \mathrm{l}$ $\mathrm{Na}_{3} \mathrm{VO}_{4}, \quad 10 \mathrm{mmol} / \mathrm{l} \quad \mathrm{NaF}, \quad 0.2 \mathrm{mmol} / \mathrm{l}$ leupeptin, $1 \mathrm{mmol} / \mathrm{l}$ benzamidine and $0.1 \mathrm{mmol} / \mathrm{l}$ 4-(2-aminoethyl)-benzenesulphonylfluoride hydrochloride) and rocked for $2 \mathrm{~h}$ at $4{ }^{\circ} \mathrm{C}$. The detergent-insoluble material was sedimented by centrifugation at $12000 \boldsymbol{g}$ for $15 \mathrm{~min}$ at $4^{\circ} \mathrm{C}$ and the supernatants collected. Protein determination was performed using the BCA protein assay kit (Pierce Chemical Co., Rockford, IL, USA) and BSA as the standard. Forty micrograms of total cellular protein were applied to each lane and were separated by SDS-PAGE and transferred to Immobilon-P membranes (Millipore, Bedford, MA, USA) and blocked overnight at $4{ }^{\circ} \mathrm{C}$ with $5 \%$ dry milk in $20 \mathrm{mmol} / \mathrm{l}$ Tris, $137 \mathrm{mmol} / \mathrm{l} \mathrm{NaCl}, \quad 0.5 \%$ Tween-20, pH 7.6. Immunological detection of IRS-1, IRS-2, p85 $\alpha / \beta$ (PI3-K) and Akt1/2 (PKB) was carried out with specific polyclonal antibodies, and immunoreactive bands were visualised using the ECL Western blotting protocol and quantified by densitometry (Molecular Analyst; Bio-Rad Laboratories, Hercules, CA, USA). Films from each set of experiments were scanned at the same time and the background signal from each single film was subtracted.

\section{Western analysis of PKB phosphorylation}

After washing four times, adipocytes (lipocrit $\sim 15 \%$ ) were incubated at $37^{\circ} \mathrm{C}$ in Medium 199 with $5.6 \mathrm{mmol} / \mathrm{l}$ glucose, $4 \%$ BSA, ADA $(1 \mathrm{U} / \mathrm{ml})$, PIA $(1 \mu \mathrm{mol} / \mathrm{l})$ with and without insulin as indicated. After 10 min incubation, cells and medium were transferred to pre-chilled tubes on ice and adipocytes were immediately separated from the medium by centrifugation through silicone oil. Cell lysis, protein determination and Western blotting procedures were performed as described above with the $\mathrm{pSer}^{473}$-PKB $\alpha$ antibody to assess the amount of phosphorylated PKB $\left(\alpha\right.$ isoform at $\operatorname{Ser}^{473}$ and $\beta$ isoform at $\operatorname{Ser}^{474}$ ). This is considered to reflect the PKB enzyme activation (18).

\section{Western analysis of total cellular membrane GLUT4}

Total cellular membranes were prepared as previously described (19). After the $24 \mathrm{~h}$ incubation period, cells were washed twice with PBS and homogenised for 30 s with a Polytron PT-MR 3000 (Kinematica AG, Littau, Switzerland) in TES homogenisation buffer $(20 \mathrm{mmol} / \mathrm{l}$ Tris-HCl, pH 7.4, $1 \mathrm{mmol} / \mathrm{l}$ EDTA, $255 \mathrm{mmol} / \mathrm{l}$ sucrose and $1 \mathrm{mmol} / \mathrm{l}$ polymethylsulphonylfluoride). The homogenate was then centrifuged at $1000 \mathrm{~g}$ for $30 \mathrm{~min}$ at $4^{\circ} \mathrm{C}$ and the supernatant collected and centrifuged at $212000 \mathrm{~g}$ for $1 \mathrm{~h}$ at $4^{\circ} \mathrm{C}$. The resulting pelleted total membrane fraction was resuspended in TES and frozen at $-70^{\circ} \mathrm{C}$. Protein determination, based on the method of Bradford (20), was performed using the Bio-Rad protein assay and bovine gamma globulin as the standard. Two micrograms of total cellular membrane protein per lane were separated by SDS-PAGE and transferred to Immobilon-P membranes and blocked overnight at $4{ }^{\circ} \mathrm{C}$ with $5 \%$ dry milk in $20 \mathrm{mmol} / \mathrm{l}$ Tris, $137 \mathrm{mmol} / \mathrm{l} \mathrm{NaCl}, 0.5 \%$ Tween-20, $\mathrm{pH}$ 7.6. Immunological detection of GLUT4 was carried out with an anti-GLUT4 polyclonal antibody, and immunoreactive bands were visualised and quantified as above.

\section{Statistics}

Statistical analyses were performed using the SPSS package (SPSS Inc., Chicago, IL, USA). Results are given as means \pm S.E.M. and statistical significance was determined using two-way ANOVA for glucose uptake and the Dunnett's test as a post-hoc test. The Kruskal-Wallis non-parametric test with a Mann-Whitney test post-hoc was used when comparing protein concentrations and insulin binding. When appropriate, $P$ values were adjusted for multiple comparisons and $P<0.05$ was considered statistically significant.

\section{Results}

\section{Glucose uptake capacity}

Adipocytes cultured in medium containing 15 or $25 \mathrm{mmol} / \mathrm{l}$ glucose for $24 \mathrm{~h}$ exhibited a clear decrease in both basal (by $\sim 30 \%$ ) and insulin-stimulated (by $\sim 20 \%$ ) D-[U- $\left.{ }^{14} \mathrm{C}\right]$ glucose uptake compared with cells incubated in 5 or $10 \mathrm{mmol} / \mathrm{l}$ glucose (Fig. 1). These actions of high glucose were not due to osmolarity effects since corresponding osmolarity changes using $20 \mathrm{mmol} / \mathrm{l}$ L-glucose $+5 \mathrm{mmol} / \mathrm{l}$ D-glucose did not alter glucose uptake capacity (data not shown). 


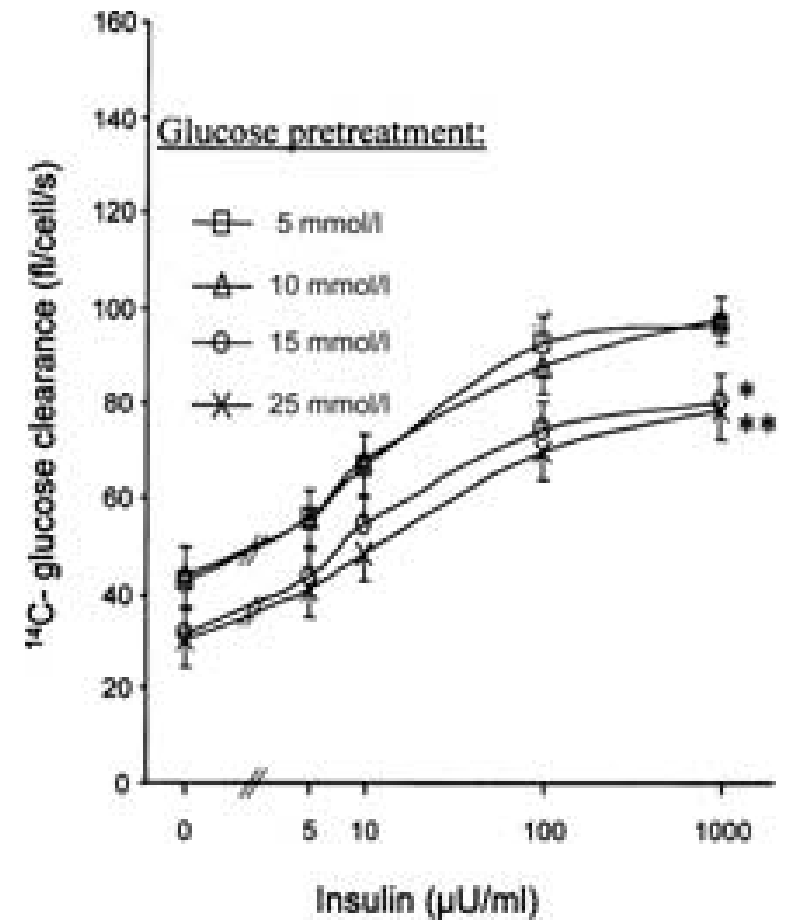

Figure 1 Effect of long-term glucose treatment on glucose uptake capacity. Adipocytes were incubated with different glucose concentrations $(5,10,15$ and $25 \mathrm{mmol} / \mathrm{l})$ for $24 \mathrm{~h}$. After washing, insulin was added at the indicated concentrations $(0-1000 \mu \mathrm{U} / \mathrm{ml})$ for $15 \mathrm{~min}$, and then glucose clearance was measured during $1 \mathrm{~h}$. The data are expressed as means \pm S.E.M. of eight separate experiments. ${ }^{*} P<0.05$ for cells cultured in $15 \mathrm{mmol} / \mathrm{l}$ glucose ${ }^{\star \star} P<0.01$ for cells cultured in $25 \mathrm{mmol} / \mathrm{l}$ glucose vs $5 \mathrm{mmol} / \mathrm{l}$ glucose respectively.

Pretreatment with a high insulin concentration $\left(10^{4} \mu \mathrm{U} / \mathrm{ml}\right)$ for $24 \mathrm{~h}$ of cells cultured at $5 \mathrm{mmol} / \mathrm{l} \mathrm{glu}$ cose did not alter subsequent basal or acutely insulinstimulated glucose uptake capacity (Fig. 2A). In contrast, at a high glucose concentration (15 mmol/l), concomitant insulin pretreatment significantly impaired glucose uptake capacity, both basal and insulin-stimulated, and the additive reduction was approximately $30-50 \%$ (Fig. 2B). The $\mathrm{EC}_{50}$ for insulin's action to acutely stimulate glucose uptake was significantly increased in cells cultured at high insulin $(52 \pm 7 \mu \mathrm{U} / \mathrm{ml}$ vs $18 \pm 3 \mu \mathrm{U} / \mathrm{ml}$ for control, $P<0.01$, inset Fig. $2 \mathrm{~A})$ at $5 \mathrm{mmol} / \mathrm{l}$ glucose. This was independent of the surrounding glucose concentration, and at $15 \mathrm{mmol} / \mathrm{l}, \mathrm{EC}_{50}$ values were $46 \pm 4$ and $22 \pm 4 \mu \mathrm{U} / \mathrm{ml}$ with and without insulin pretreatment respectively ( $P<0.01$, inset Fig. $2 \mathrm{~B})$.

In some experiments, cells were cultured with high glucose and insulin during the final 2 or $6 \mathrm{~h}$ of the $24 \mathrm{~h}$ incubation. These time-course experiments revealed that high insulin and glucose in combination had already induced a $\sim 20 \%$ decrease in glucose uptake capacity after $2 \mathrm{~h}$ (Fig. 2C). After $6 \mathrm{~h}$ of high insulin and glucose a further decrease in glucose uptake was seen and it was similar to that with a $24 \mathrm{~h}$ treatment. Two and $6 \mathrm{~h}$ of high glucose in the absence of insulin did not impair glucose uptake capacity (not shown).

\section{Insulin binding}

The glucose concentration of the culture medium did not per se affect cell surface ${ }^{125}$ I-insulin binding and it was similar following 5 and $15 \mathrm{mmol} / \mathrm{l}$ glucose $\left(0.71 \pm 0.17\right.$ vs $0.69 \pm 0.15 \mathrm{pg} / 10^{5}$ cells respectively, $n=4, P=$ not significant). Pretreatment with insulin at a high concentration $\left(10^{4} \mu \mathrm{U} / \mathrm{ml}\right)$ for $24 \mathrm{~h}$ induced a $\sim 45 \%$ decrease in ${ }^{125}$ I-insulin binding compared with the control situation without insulin $\left(0.39 \pm 0.11\right.$ and $0.39 \pm 0.10 \mathrm{pg} / 10^{5}$ cells for cells cultured in 5 and $15 \mathrm{mmol} / \mathrm{l}$ glucose respectively, $n=4$, $P<0.05$ vs no insulin), and, thus, the effect of insulin pretreatment was independent of the surrounding glucose concentration.

\section{Cellular content of insulin signalling proteins}

High glucose levels in the surrounding medium exerted opposite effects on the expression of IRS-1 and -2. High glucose downregulated IRS-1 expression by up to $\sim 50 \%$ (Fig. 3A). In contrast, IRS-2 was markedly upregulated, up to 5-fold, in fat cells surrounded by glucose levels of $10 \mathrm{mmol} / \mathrm{l}$ or more as compared with $5 \mathrm{mmol} / \mathrm{l}$ glucose and this occurred in a concentration-dependent manner (Fig. 3B). High glucose in the medium exerted no significant changes in PI3-K and PKB levels (Fig. 3C and D).

High levels of insulin $\left(10^{4} \mu \mathrm{U} / \mathrm{ml}\right)$ in the incubation medium markedly reduced IRS-2 expression by $\sim 60-$ $95 \%$, and the most pronounced effect was seen when cells were concomitantly exposed to the highest glucose concentration, i.e. $25 \mathrm{mmol} / \mathrm{l}$ (Fig. 3B). High insulin $\left(10^{4} \mu \mathrm{U} / \mathrm{ml}\right)$ produced no consistent effects on IRS-1, PI3-K and PKB content when the glucose level was physiological or near-physiological $(5$ or $10 \mathrm{mmol} / \mathrm{l}$, Fig. 3A, C and D), but the concomitant presence of high insulin and high glucose in the medium exerted a further decrease in IRS-1 compared with high glucose alone. Thus, IRS- 1 content was decreased by $\sim 70 \%$ in cells cultured in $15 \mathrm{mmol} / \mathrm{l}$ glucose and high insulin compared with $15 \mathrm{mmol} / \mathrm{l}$ glucose alone, and by $\sim 80 \%$ compared with the control situation, i.e. $5 \mathrm{mmol} / \mathrm{l}$ and no insulin (Fig. 3A). Also for IRS-2, there was an interaction effect for high insulin and high glucose in combination, and IRS-2 abundance was reduced by $\sim 60-70 \%$ compared with high insulin alone (Fig. 3B). In fact, glucose exerted a concentration-dependent suppressing effect on the IRS-2 amount in the presence of high insulin, i.e. opposite to the glucose effect alone. The combination of insulin and high glucose in the incubation medium did not exert any significant alterations in the levels of PI3-K 
(assessed by immunoblotting of the $\mathrm{p} 85 \alpha / \beta$ subunit) or of $\mathrm{PKB}$, although there was a tendency for increased PKB content following high insulin treatment when
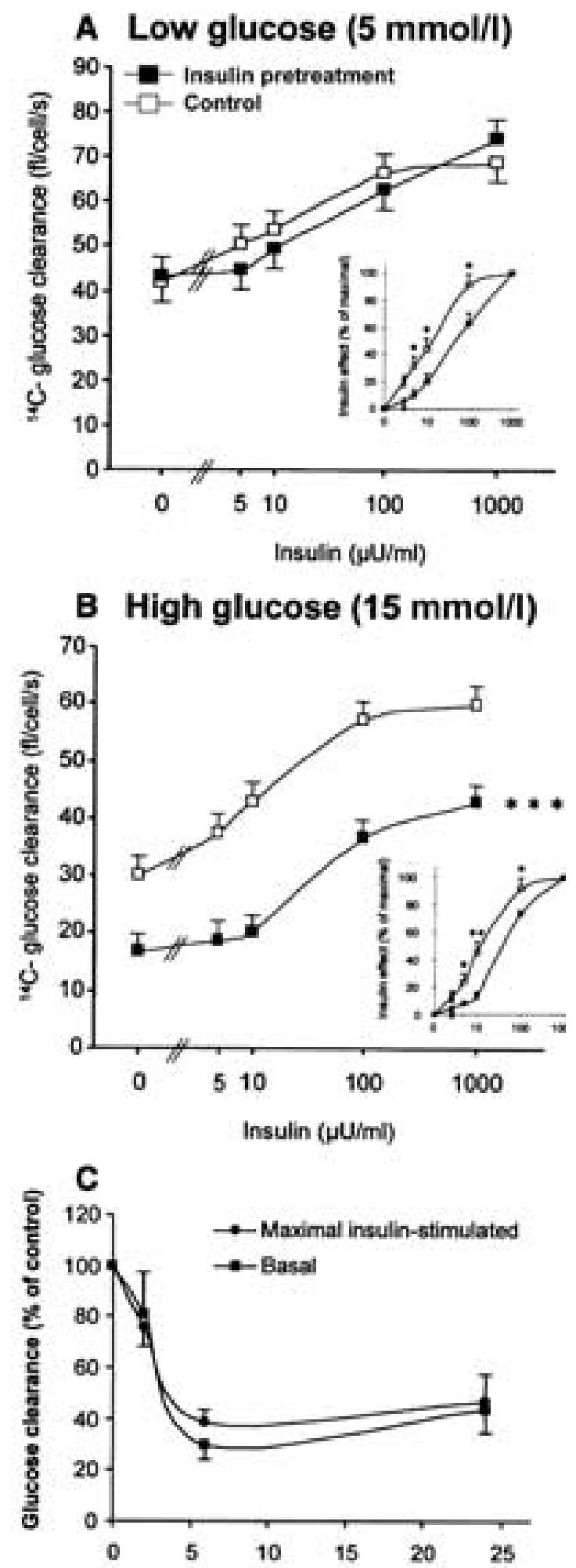

Incubation time with high glucose and insulin (h) the glucose level was high (Fig. 3C). Overall, there were in fact no consistent changes in the amount of PI3-K or PKB following any of the various incubation conditions (Fig. $3 \mathrm{C}$ and D).

\section{PKB phosphorylation}

Insulin pretreatment for $24 \mathrm{~h}$ caused an elevated basal phosphorylation of $\mathrm{PKB}$, probably due to a sustained insulin-stimulated phosphorylation remaining after washing. However, the amount of Ser ${ }^{473}$-phosphorylated PKB following acute stimulation by insulin $(1000 \mu \mathrm{U} / \mathrm{ml})$ for $10 \mathrm{~min}$ was not affected by prior pretreatment with high glucose or insulin, alone or in combination, for $24 \mathrm{~h}$ (Fig. 4A). This was true also when calculating the degree of phosphorylation, i.e. the amount of phosphorylated PKB per amount of total PKB protein (data not shown). In additional experiments we examined the dose-response relationship for insulin's ability to acutely phosphorylate PKB. Concomitant incubation with high insulin and glucose induced a significant rightward shift in the doseresponse curve $\left(\mathrm{EC}_{50} 92 \pm 23\right.$ and $155 \pm 42 \mu \mathrm{U} / \mathrm{ml}$ for control cells and cells cultured in $15 \mathrm{mmol} / \mathrm{l}$ glucose plus insulin respectively, $n=4, P<0.05$, Fig. 4B). In contrast, high glucose $(15 \mathrm{mmol} / \mathrm{l})$ or high insulin alone also tended to shift the dose-response curve for insulin-stimulated PKB phosphorylation to the right, but to a lesser extent (EC $\mathrm{EC}_{50} 109 \pm 31$ and $122 \pm$ $34 \mu \mathrm{U} / \mathrm{ml}$ respectively, $n=4, P=\mathrm{NS}$ ).

\section{Cellular GLUT4 content}

Insulin in the medium did not affect the amount of cellular membrane-associated GLUT4 when the glucose level was low (Fig. 5). However, $15 \mathrm{mmol} / \mathrm{l}$ glucose in the medium for $24 \mathrm{~h}$ by itself induced an increase in total membrane GLUT4 by $\sim 140 \%$ as compared with $5 \mathrm{mmol} / \mathrm{l}$ glucose. Concomitant incubation with high insulin completely prevented this glucose-induced upregulation and the GLUT4 content remained at similar levels to those in the control situation (Fig. 5).

Figure 2 Effect of insulin pretreatment at a high level on glucose uptake capacity. Adipocytes were incubated in $5 \mathrm{mmol} / \mathrm{l}(A)$ or $15 \mathrm{mmol} / \mathrm{l}(B)$ glucose with $(\square)$ or without $(\square)$ insulin $\left(10^{4} \mu \mathrm{U} / \mathrm{ml}\right)$ for $24 \mathrm{~h}$. (C) Time course for the effects of pretreatment with high glucose and insulin to reduce basal and maximally insulin-stimulated glucose uptake. Adipocytes were exposed to high glucose $(15 \mathrm{mmol} / \mathrm{l})$ and insulin $\left(10^{4} \mu \mathrm{U} / \mathrm{ml}\right)$ for the final 2,6 and $24 \mathrm{~h}$ of incubation $(0=$ control situation with $5 \mathrm{mmol} / \mathrm{l}$ glucose). After washing, insulin was added at the indicated concentrations (0$1000 \mu \mathrm{U} / \mathrm{ml}$ ) for $15 \mathrm{~min}$, and then glucose clearance was measured in the presence of different insulin concentrations (0$1000 \mu \mathrm{U} / \mathrm{ml}$ ) during $1 \mathrm{~h}$. Insets: data expressed as insulin effect (\% of maximal glucose uptake). All data are means \pm S.E.M. of eight or nine $(A, B)$ or six $(C)$ separate experiments. ${ }^{*} P<0.05$, ${ }^{\star \star} P<0.01,{ }^{* \star} P<0.001$ vs control situation (no insulin). 


\section{Discussion}

In the present study we have exposed primary cultured rat adipocytes to different glucose concentrations in the presence or absence of a high insulin level. This may reflect the natural course of the development of type 2 diabetes, i.e. hyperinsulinaemia alone that compensates for insulin resistance in vivo, hyperinsulinaemia together with hyperglycaemia and hyperglycaemia alone. Our results show that high levels of insulin and glucose in combination have deleterious effects on insulin sensitivity, glucose uptake capacity, the cellular content of IRS-1 and -2 and activation of PKB in rat fat cells.

We treated adipocytes for $24 \mathrm{~h}$ with insulin at a supraphysiological concentration, to ensure a saturating insulin effect throughout the incubation and this did not alter basal or insulin-stimulated glucose uptake capacity when the culture medium contained a low glucose level. However, high insulin and high glucose in combination suppressed both basal and insulinstimulated glucose uptake and the maximal impairment seemed to occur within $6 \mathrm{~h}$ of incubation. Previously, Garvey et al. (21) reported that a high glucose level amplifies a long-term effect of insulin to impair glucose transport rates. In addition, the translocation of glucose transporters to the cell surface was impaired. We found that excess insulin, independent of glucose concentration, for $24 \mathrm{~h}$ induced a decrease in insulin sensitivity, as shown by a 2- to 3-fold rightward shift in the dose-response curve for glucose transport stimulation. This could, quantitatively, be
A

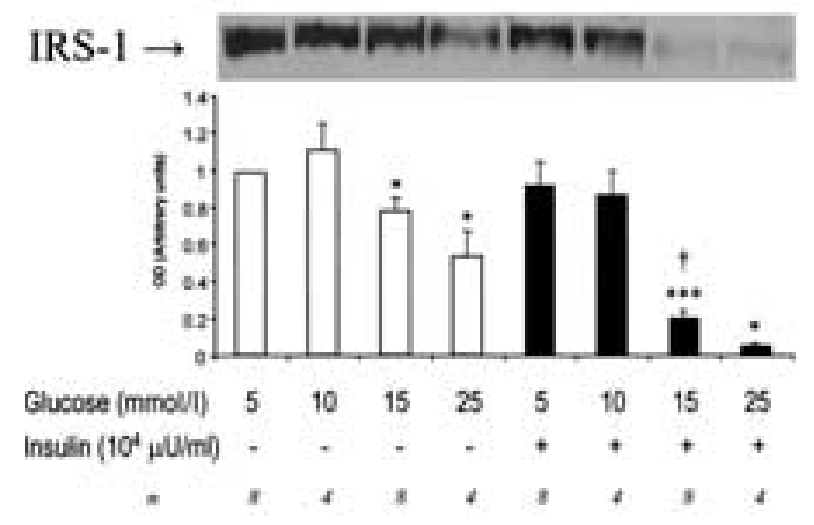

B

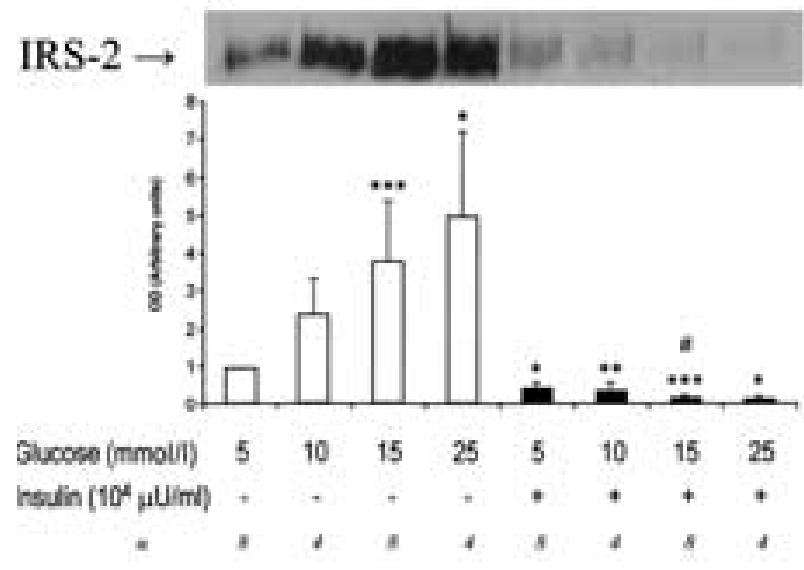

C

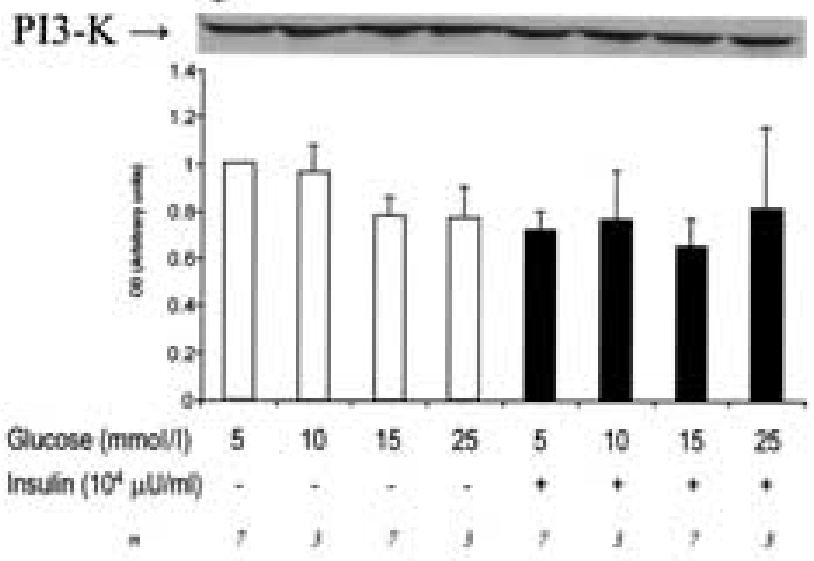

D

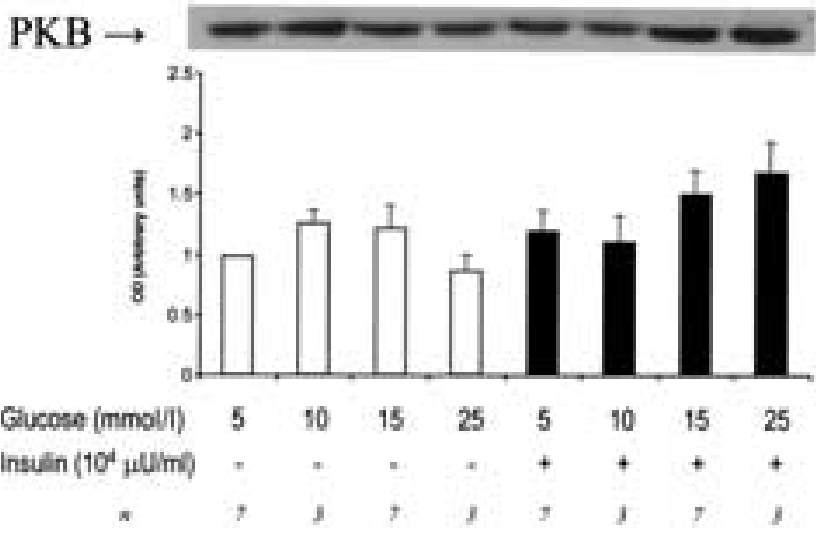

Figure 3 Cellular content of insulin signalling proteins. Whole cell lysates were prepared from adipocytes incubated for $24 \mathrm{~h}$ in different glucose concentrations (5, 10,15 and $25 \mathrm{mmol} / \mathrm{l})$ in the absence (open bars) or presence (filled bars) of insulin $\left(10^{4} \mu \mathrm{U} / \mathrm{ml}\right.$ ). Whole cell lysates were separated on SDS-PAGE, transferred to nitrocellulose membranes and immunoblotted with antibodies against IRS-1 (A), IRS-2 (B), p85 / / (PI3-K) (C) and Akt1/2 (PKB) (D). The data are expressed as means \pm S.E.M. of three to eight separate experiments as indicated. One representative blot is shown. The results of video densitometry analysis are shown and are expressed as arbitrary units of the amount of signalling protein in relation to the control situation (i.e. $5 \mathrm{mmol} / \mathrm{l}$ glucose, no insulin $=1$ arbitrary unit). ${ }^{*} P<0.05$, ${ }^{* *} P<0.01,{ }^{* * \star} P<0.001$ vs control; ${ }^{\dagger} P<0.05$ vs $15 \mathrm{mmol} / / \mathrm{glucose}$ without insulin and vs $5 \mathrm{mmol} / \mathrm{l}+\mathrm{insulin} ;{ }^{\#} P<0.05 \mathrm{vs} 5 \mathrm{mmol} / \mathrm{lglu}-$ cose+insulin. For PI3-K and PKB no significant alterations were seen with any of the employed treatments (C, D). 
A

\section{pSer ${ }^{473}-\mathrm{PKB}$}

Acute insulin stimulation $10 \mathrm{~min}(1000 \mu \mathrm{U} / \mathrm{ml})$

Glucose pretreatment $24 \mathrm{~h}(\mathrm{mmol} / 1)$
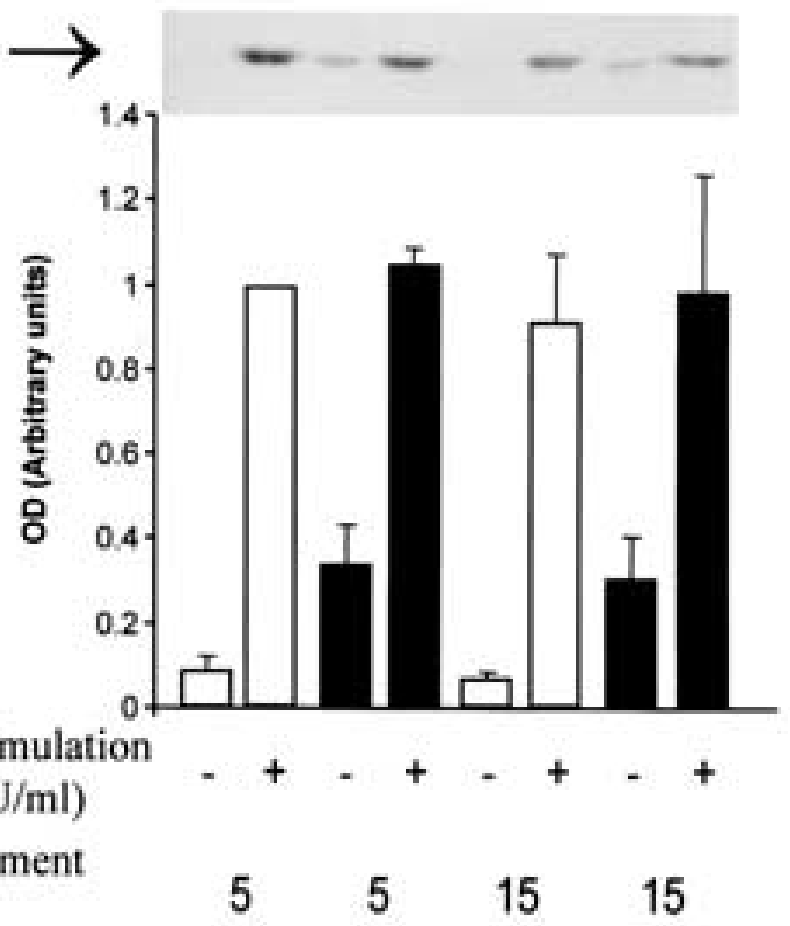

15

15

\section{B} Control

\section{pSer ${ }^{473}$-PKB}

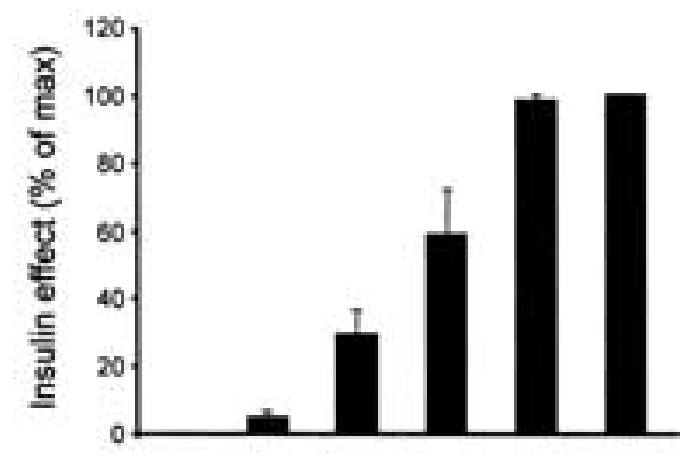

Insulin conc. $(\mu \mathrm{U} / \mathrm{ml}) \quad 0 \quad 10 \quad 501005001000$
High glucose and insulin
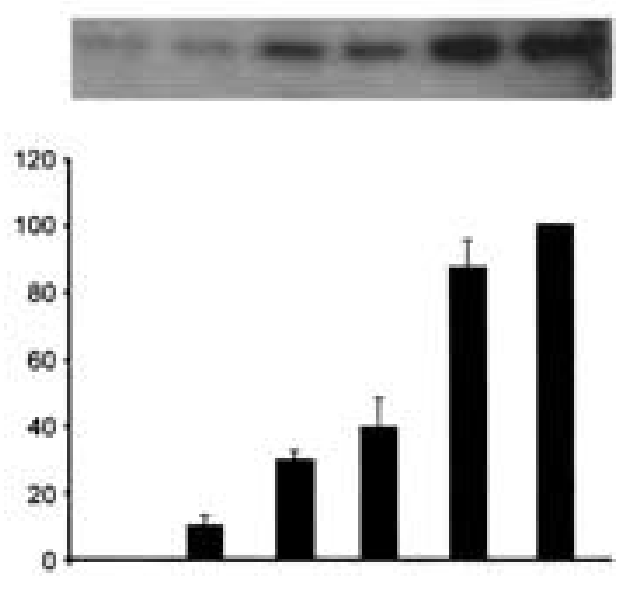

$0 \quad 10501005001000$

Figure 4 Effect of long-term high glucose and insulin on insulin-stimulated PKB phosphorylation. Isolated cells were cultured for $24 \mathrm{~h}$ in 5 or $15 \mathrm{mmol} / \mathrm{l}$ glucose without insulin (open bars) or with $10^{4} \mu \mathrm{U} / \mathrm{ml}$ insulin (filled bars). After washing, cells were treated either with or without insulin $(1000 \mu \mathrm{U} / \mathrm{ml})$ for $10 \mathrm{~min}(\mathrm{~A})$ or the dose-response relationship for insulin's acute effect was examined with varying insulin concentrations as indicated (B). Then, total cellular lysates were prepared as described in Materials and methods and protein from total cellular lysates was separated on SDS-PAGE, followed by immunoblotting using an anti-phospho-Akt1 (Ser ${ }^{473}$ ) antibody. One representative blot is shown. The results of video densitometry analysis are shown and are expressed as arbitrary units in relation to the amount of $\mathrm{Ser}^{473}$ phosphorylation in the control culture condition (i.e. $5 \mathrm{mmol} / /$ glucose, no insulin = 1 arbitrary unit) after acute insulin stimulation. Data are means \pm S.E.M. of four or five separate experiments. 


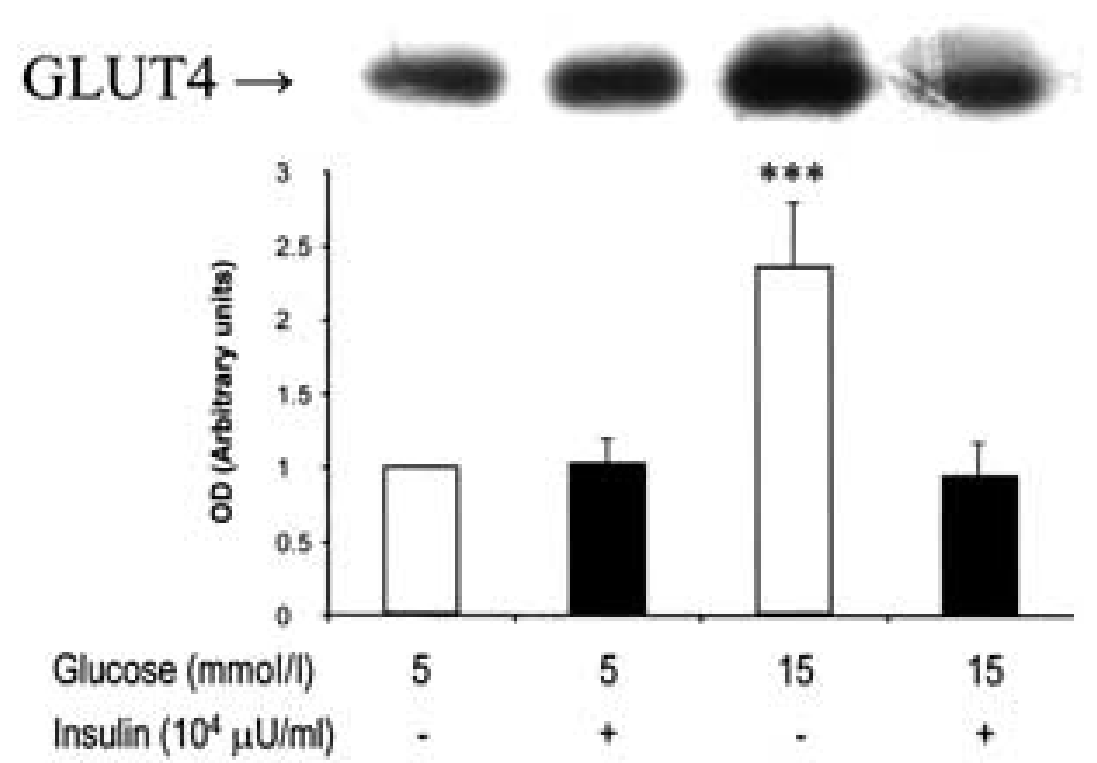

Figure 5 GLUT4 content in total cellular membranes. Adipocytes were incubated for $24 \mathrm{~h}$ in 5 or $15 \mathrm{mmol} / \mathrm{l}$ glucose with $10^{4} \mu \mathrm{U} / \mathrm{ml}$ insulin (filled bars) or without insulin (open bars). After washing, total cellular membranes were prepared as described in Materials and methods. Protein from total cellular membranes was separated on SDSPAGE, transferred to nitrocellulose membranes and immunoblotted with antibodies against GLUT4. The data are expressed as means \pm S.E.M. of 13 separate experiments. One representative blot is shown. The results of video densitometry analysis are shown and data are expressed as arbitrary units of the amount of GLUT4 in relation to the control situation (i.e. $5 \mathrm{mmol} / \mathrm{l}$ glucose, no insulin $=1$ arbitrary unit). ${ }^{* *} P<0.001$ vs control. explained by the $\sim 50 \%$ reduction in cell surface insulin binding capacity following insulin pretreatment as presently demonstrated, which is in accord with a downregulation of the number of insulin binding sites reported previously (21). However, in a recent study by Tang et al. (22) high glucose and insulin were reported not to affect total cellular insulin receptor content or basal insulin receptor phosphorylation, whereas maximal insulin stimulation of the insulin receptor was decreased in cells exposed to high glucose and insulin.

Our present work shows that long-term exposure to a high glucose level per se can impair the glucose transport system in adipocytes by reducing the rate of insulin-stimulated as well as basal glucose uptake. It appears that there is a threshold for this effect that occurs between 10 and $15 \mathrm{mmol} / \mathrm{l}$. In harmony with our present data, it was previously reported that in muscle from human type 2 diabetes, insulin-stimulated glucose transport is impaired under hyperglycaemic conditions (23). However, the glucose transport capacity was restored in vitro during incubation at a physiological glucose level, supporting the proposition that glucose levels per se have regulatory effects on the glucose transport machinery (23). We recently found that insulin-resistant adipocytes from type 2 diabetes patients recover their insulin response after in vitro incubation at physiological glucose levels for $24 \mathrm{~h}$, suggesting that cellular insulin resistance may be secondary to the hyperglycaemic state in vivo (24). Moreover, isolated fat cells from normoglycaemic individuals with a strong family history of type 2 diabetes displayed normal insulin action on glucose uptake and lipolysis, despite whole-body insulin resistance in vivo (15). These observations may suggest that cellular insulin resistance is a consequence rather than a cause of hyperglycaemia in type 2 diabetes.

High insulin in the incubation medium markedly impaired cellular IRS-2 expression at both low and high glucose levels. To the best of our knowledge this has not been reported previously. Recent studies have revealed an important role for IRS-2 in the liver $(25,26)$.

Previous studies have found that long-term insulin treatment downregulates IRS-1 in 3T3-L1 adipocytes (27-29). However, 3T3-L1 cells are normally cultured in high glucose $(25 \mathrm{mmol} / \mathrm{l})$. We demonstrate that insulin does not reduce IRS-1 content at physiological glucose levels in primary cultured adipocytes, and that a prerequisite for insulin-induced downregulation of IRS-1 is high glucose (i.e. $15 \mathrm{mmol} / \mathrm{l}$ or more) surrounding the cells. We found that IRS-1 content in adipocytes is almost halved in the presence of $25 \mathrm{mmol} / \mathrm{l}$ glucose. In contrast, IRS-2 displayed a distinct upregulation that was closely linked to the prevailing glucose concentration in the incubation medium, and this is a novel finding. This is compatible with results of Rondinone et al. (30) showing that individuals with type 2 diabetes have a marked reduction in adipocyte IRS-1 protein expression and function, whereas IRS-2 is upregulated and could be the main docking protein binding to and activating PI3-K. It could be argued that the adipose tissue plays a minor role in overall insulinmediated glucose turnover in vivo. However, similar alterations in insulin signalling may occur also in skeletal muscle in both human type 2 diabetes $(31,32)$ and animal models (33-35) of type 2 diabetes. For example in Zucker diabetic fatty rats (35) and $o b / o b$ mice (36) displaying hyperglycaemia combined with hyperinsulinaemia, the expression of IRS-1 and -2 in muscle is reduced, similar to our present findings. 
Our study shows that combined treatment for $24 \mathrm{~h}$ with high insulin and high glucose produced a massive reduction in the content of IRS-1 and -2 indicating synergistic interaction effects between insulin and glucose. These insulin- and glucose-induced aberrations in the amount of insulin signalling proteins might be of relevance for the development and progression of human type 2 diabetes, as also supported by data from mice with combined heterozygous null mutations suggesting that combined IRS-1 and -2 perturbations may contribute to the development of diabetes (37). In our study high insulin markedly reduced IRS-2 content. Moreover, insulin further decreased IRS-1 content compared with cells cultured in high glucose alone. It has been reported that low cellular IRS-1 expression in fat cells from healthy humans is associated with impaired downstream signalling and also insulin resistance in vivo $(38,39)$. Our present data also support the concept that low IRS-1 content is associated with a suppression of the glucose transport system, since the conditions displaying a reduced glucose uptake capacity, i.e. high glucose or high glucose+high insulin, also caused depletion of IRS-1. In contrast, we found no consistent alterations in the cellular content of PI3-K or $\mathrm{PKB}$, and moreover, maximally insulin-stimulated PKB phosphorylation was not impaired by the high glucose+high insulin condition. Nevertheless, in our study pretreatment with high glucose and high insulin shifted the dose-response curve for insulin to phosphorylate $\mathrm{PKB}$ to the right and the effect of acutely phosphorylating PKB exerted by submaximal insulin concentrations was impaired. This is an indication of impaired upstream signalling that could be explained by reduced IRS-1 and -2 content and/or the demonstrated insulin-induced reduction in cell surface insulin binding capacity. However, in our high glucose+ insulin model the maximal incremental response to insulin with respect to PKB phosphorylation as well as glucose transport was essentially preserved, although the amounts of IRS- 1 and -2 were markedly decreased. This is compatible with recent findings suggesting that insulin can produce PKB phosphorylation in skeletal muscle of insulin-resistant humans despite a complete inability to stimulate IRS-1 phosphorylation (40). One possible explanation could be that small amounts of IRS- 1 and -2 are enough for signal transduction to PKB and that there is normally a great redundancy in IRS levels. Furthermore, it cannot be excluded that other signalling pathways downstream of the insulin receptor could substitute for IRS-1 and -2. Nevertheless, in our insulin-resistant adipocyte model, the demonstrated reduction in PKB activation at submaximal insulin concentrations could be a consequence of the combined depletion of IRS-1 and -2 content. Of note, there are other studies that suggest that reduced amounts of IRS-1 are associated with a reduction in PKB activity in human (38) as well as rat (41) adipocytes.
In this study, we found no effect of high insulin for $24 \mathrm{~h}$ per se on the cellular GLUT4 content when glucose was at a low level, but when combined with a high glucose level $(15 \mathrm{mmol} / \mathrm{l})$, insulin exerted a suppressing effect, i.e. preventing the upregulation produced by high glucose alone. A previous study in 3T3-L1 adipocytes showed that prolonged insulin treatment decreases GLUT4 content by 30\% (42). Our group has recently reported that insulin instead exerts an upregulating effect on GLUT4 mRNA and protein levels in 3T3-F442A adipocytes at low $(5.6 \mathrm{mmol} / \mathrm{l})$ but not high $(25 \mathrm{mmol} / \mathrm{l})$ glucose levels (12). In comparison with the present results those data emphasise that one cannot directly extrapolate cell-line data to tissues in animals or humans.

Our present results show that long-term high glucose per se downregulated both basal and maximally stimulated glucose uptake capacity despite a clear concentration-dependent accumulation of GLUT4 protein in the total cellular membrane fraction, suggesting a deleterious effect on the translocation process or the intrinsic activity of GLUT4 (43). In rats with streptozotocin-induced diabetes, hyperglycaemia per se affects insulin-stimulated glucose transport by altering glucose transporter translocation in skeletal muscle (44). The impairment of glucose uptake in adipocytes does not seem to involve GLUT1 since it was unaffected by high glucose in diabetic rats $(45,46)$.

The mechanisms for glucose- and insulin-induced alterations in IRS-1 and -2 as well as GLUT4 abundance are not clarified. Preliminary data from our laboratory suggest that high insulin and high glucose do not alter IRS-1 gene transcription (F Renström, J Burén \& J W Eriksson, unpublished observations). This is in accord with data from 3T3-L1 adipocytes where expression of IRS-1 mRNA was essentially unchanged following chronic exposure to insulin, but the rate of IRS-1 protein degradation seemed to be increased (27). Recent data from CHO cells and 3T3-L1 adipocytes suggest that insulin promotes IRS-1 degradation by the proteasome degradation pathway (47).

In summary, our data demonstrate that long-term high insulin and high glucose, particularly in combination, can produce, within $24 \mathrm{~h}$ of adipose cell culture, marked alterations in glucose uptake capacity, IRS-1/2 and GLUT4 content and in insulin's ability to phosphorylate PKB. Following insulin pretreatment, cell surface insulin binding is decreased and together with IRS depletion this may contribute to the demonstrated insensitivity to insulin's action on PKB activation and glucose transport. These alterations in the insulin signalling cascade and glucose transport system may potentially promote insulin resistance in the different stages of progression of human type 2 diabetes. Alterations in the insulin signalling pathway in type 2 diabetes, e.g. decreased cellular IRS-1 content, may be, at least partly, secondary to the diabetic state. 
In conclusion, our data suggest that: (i) hyperinsulinaemia and hyperglycaemia in combination severely compromise adipocyte insulin binding and IRS-1 and -2 content; (ii) this is accompanied by an impaired sensitivity for insulin with respect to PKB and glucose transport activation; (iii) there is a great redundancy in IRS- 1 and -2 amounts in normal cells; and (iv) cellular insulin resistance in diabetes may be aggravated by alterations in glucose and insulin levels in vivo.

\section{Acknowledgements}

We are grateful to Ewa Strömqvist-Engbo for skilful experimental work and assistance. We thank Dr Jørgen Jensen for valuable advice on the PKB phosphorylation experiments and Frida Renström for analysis of PKB phosphorylation. This work was supported by the Swedish Research Council (Medicine, projects 14287 and 12663), the Swedish Diabetes Association, the Faculty of Medicine at Umeå University, Novo Nordisk Pharma AB, Novo Nordisk, the Elsa and Folke Sahlberg, the Sigurd and Elsa Golje and the Torsten and Ragnar Söderberg Foundations, and the Swedish Institute.

\section{References}

1 Yki-Jarvinen H, Helve E \& Koivisto VA. Hyperglycemia decreases glucose uptake in type I diabetes. Diabetes 198736 892-896.

2 DeFronzo RA, Simonson D \& Ferrannini E. Hepatic and peripheral insulin resistance: a common feature of type 2 (non-insulindependent) and type 1 (insulin-dependent) diabetes mellitus. Diabetologia 198223 313-319.

3 Reaven GM \& Olefsky JM. The role of insulin resistance in the pathogenesis of diabetes mellitus. Advances in Metabolic Disorders $19789313-331$.

4 Gavin JR, Roth J, Neville DM, de Meyts P \& Buell DN. Insulindependent regulation of insulin receptor concentrations: a direct demonstration in cell culture. PNAS 197471 84-88.

5 Vuorinen-Markkola H, Koivisto VA \& Yki-Jarvinen H. Mechanisms of hyperglycemia-induced insulin resistance in whole body and skeletal muscle of type I diabetic patients. Diabetes $199241571-580$.

6 Richter EA, Hansen BF \& Hansen SA. Glucose-induced insulin resistance of skeletal-muscle glucose transport and uptake. Biochemical Journal $1988252733-737$.

7 Rossetti L, Hawkins M, Chen W, Gindi J \& Barzilai N. In vivo glucosamine infusion induces insulin resistance in normoglycemic but not in hyperglycemic conscious rats. Journal of Clinical Investigation $199596132-140$.

8 Muller HK, Kellerer M, Ermel B, Muhlhofer A, Obermaier-Kusser $\mathrm{B}$, Vogt $\mathrm{B}$ et al. Prevention by protein kinase $\mathrm{C}$ inhibitors of glucose-induced insulin-receptor tyrosine kinase resistance in rat fat cells. Diabetes 199140 1440-1448.

9 Berti L, Mosthaf L, Kroder G, Kellerer M, Tippmer S, Mushack J et al. Glucose-induced translocation of protein kinase $\mathrm{C}$ isoforms in rat-1 fibroblasts is paralleled by inhibition of the insulin receptor tyrosine kinase. Journal of Biological Chemistry 1994269 $3381-3386$.

10 Rossetti L \& Giaccari A. Relative contribution of glycogen synthesis and glycolysis to insulin-mediated glucose uptake. A doseresponse euglycemic clamp study in normal and diabetic rats. Journal of Clinical Investigation 199085 1785-1792.
11 Cline GW, Petersen KF, Krssak M, Shen J, Hundal RS, Trajanoski Z et al. Impaired glucose transport as a cause of decreased insulinstimulated muscle glycogen synthesis in type 2 diabetes. New England Journal of Medicine $1999341240-246$.

$12 \mathrm{Yu}$ ZW, Burén J, Enerbäck S, Nilsson E, Samuelsson L \& Eriksson JW. Insulin can enhance GLUT4 gene expression in 3T3-F442A cells and this effect is mimicked by vanadate but counteracted by cAMP and high glucose - potential implications for insulin resistance. Biochimica et Biophysica Acta 20011535 174-185.

13 Smith U, Sjostrom L \& Bjornstorp P. Comparison of two methods for determining human adipose cell size. Journal of Lipid Research $197213822-824$.

14 Yu ZW, Jansson PA, Posner BI, Smith U \& Eriksson JW. Peroxovanadate and insulin action in adipocytes from NIDDM patients. Evidence against a primary defect in tyrosine phosphorylation. Diabetologia 199740 1197-1203.

15 Eriksson JW, Smith U, Waagstein F, Wysocki M \& Jansson PA. Glucose turnover and adipose tissue lipolysis are insulin-resistant in healthy relatives of type 2 diabetes patients: is cellular insulin resistance a secondary phenomenon? Diabetes $1999 \mathbf{4 8}$ $1572-1578$.

16 Eriksson J, Lonnroth P \& Smith U. Insulin can rapidly increase cell surface insulin binding capacity in rat adipocytes. A novel mechanism related to insulin sensitivity. Diabetes $1992 \mathbf{4 1} 707-714$.

17 Kashiwagi A, Verso MA, Andrews J, Vasquez B, Reaven G \& Foley JE. In vitro insulin resistance of human adipocytes isolated from subjects with noninsulin-dependent diabetes mellitus. Journal of Clinical Investigation 198372 1246-1254.

18 Goransson O, Resjo S, Ronnstrand L, Manganiello V \& Degerman E. Ser-474 is the major target of insulin-mediated phosphorylation of protein kinase $\mathrm{B}$ beta in primary rat adipocytes. Cellular Signalling 200214 175-182.

19 Kitzman HH, McMahon RJ, Williams MG \& Frost SC. Effect of glucose deprivation of GLUT 1 expression in 3T3-L1 adipocytes. Journal of Biological Chemistry 1993268 1320-1325.

20 Bradford MM. A rapid and sensitive method for the quantitation of microgram quantities of protein utilizing the principle of protein-dye binding. Analytical Biochemistry 197672 248-254.

21 Garvey WT, Olefsky JM, Matthaei S \& Marshall S. Glucose and insulin co-regulate the glucose transport system in primary cultured adipocytes. A new mechanism of insulin resistance. Journal of Biological Chemistry 1987262 189-197.

22 Tang S, Le-Tien H, Goldstein BJ, Shin P, Lai R \& Fantus IG. Decreased in situ insulin receptor dephosphorylation in hyperglycemia-induced insulin resistance in rat adipocytes. Diabetes 2001 50 83-90.

23 Zierath JR, Galuska D, Nolte LA, Thorne A, Kristensen JS \& Wallberg-Henriksson $\mathrm{H}$. Effects of glycaemia on glucose transport in isolated skeletal muscle from patients with NIDDM: in vitro reversal of muscular insulin resistance. Diabetologia 1994 37 270-277.

24 Burén J. Lindmark S, Renström F \& Eriksson JW. In vitro reversal of hyperglycemia normalizes insulin action in fat cells from type 2 diabetes patients: is cellular insulin resistance caused by glucotoxicity in vivo. Metabolism 2003 (In Press).

25 Shimomura I, Matsuda M, Hammer RE, Bashmakov Y, Brown MS \& Goldstein JL. Decreased IRS-2 and increased SREBP-1c lead to mixed insulin resistance and sensitivity in livers of lipodystrophic and ob/ob mice. Molecular Cell 20006 77-86.

26 Kubota N, Tobe K, Terauchi Y, Eto K, Yamauchi T, Suzuki R et al. Disruption of insulin receptor substrate 2 causes type 2 diabetes because of liver insulin resistance and lack of compensatory beta-cell hyperplasia. Diabetes 200049 1880-1889.

27 Rice KM, Turnbow MA \& Garner CW. Insulin stimulates the degradation of IRS-1 in 3T3-L1 adipocytes. Biochemical and Biophysical Research Communications 1993190 961-967.

28 Ricort JM, Tanti JF, Van Obberghen E \& Le Marchand-Brustel Y. Alterations in insulin signalling pathway induced by prolonged 
insulin treatment of 3T3-L1 adipocytes. Diabetologia $19953 \mathbf{8}$ $1148-1156$.

29 Pederson TM, Kramer DL \& Rondinone CM. Serine/threonine phosphorylation of IRS-1 triggers its degradation: possible regulation by tyrosine phosphorylation. Diabetes 200150 24-31.

30 Rondinone CM, Wang LM, Lonnroth P, Wesslau C, Pierce JH \& Smith U. Insulin receptor substrate (IRS) 1 is reduced and IRS-2 is the main docking protein for phosphatidylinositol 3-kinase in adipocytes from subjects with non-insulin-dependent diabetes mellitus. PNAS 199794 4171-4175.

31 Bjornholm M, Kawano Y, Lehtihet M \& Zierath JR. Insulin receptor substrate-1 phosphorylation and phosphatidylinositol 3-kinase activity in skeletal muscle from NIDDM subjects after in vivo insulin stimulation. Diabetes $199746524-527$.

32 Krook A, Roth RA, Jiang XJ, Zierath JR \& Wallberg-Henriksson H. Insulin-stimulated Akt kinase activity is reduced in skeletal muscle from NIDDM subjects. Diabetes 1998 47 1281-1286.

33 Folli F, Saad MJ, Backer JM \& Kahn CR. Regulation of phosphatidylinositol 3-kinase activity in liver and muscle of animal models of insulin-resistant and insulin-deficient diabetes mellitus. Journal of Clinical Investigation 199392 1787-1794.

34 Saad MJ, Folli F, Kahn JA \& Kahn CR. Modulation of insulin receptor, insulin receptor substrate-1, and phosphatidylinositol 3-kinase in liver and muscle of dexamethasone-treated rats. Journal of Clinical Investigation 199392 2065-2072.

35 Anai M, Funaki M, Ogihara T, Terasaki J, Inukai K, Katagiri H et al. Altered expression levels and impaired steps in the pathway to phosphatidylinositol 3-kinase activation via insulin receptor substrates 1 and 2 in Zucker fatty rats. Diabetes 1998 47 13-23.

36 Kerouz NJ, Horsch D, Pons S \& Kahn CR. Differential regulation of insulin receptor substrates-1 and -2 (IRS-1 and IRS-2) and phosphatidylinositol 3-kinase isoforms in liver and muscle of the obese diabetic (ob/ob) mouse. Journal of Clinical Investigation $1997 \mathbf{1 0 0}$ 3164-3172.

37 Kido Y, Burks DJ, Withers D, Bruning JC, Kahn CR, White MF et al. Tissue-specific insulin resistance in mice with mutations in the insulin receptor, IRS-1, and IRS-2. Journal of Clinical Investigation 2000105 199-205.

38 Carvalho E, Jansson PA, Nagaev I, Wenthzel AM \& Smith U. Insulin resistance with low cellular IRS-1 expression is also associated with low GLUT4 expression and impaired insulin-stimulated glucose transport. FASEB Journal 200115 1101-1103.
39 Carvalho E, Jansson PA, Axelsen M, Eriksson JW, Huang X, Groop L et al. Low cellular IRS 1 gene and protein expression predict insulin resistance and NIDDM. FASEB Journal 199913 $2173-2178$.

40 Storgaard H, Song XM, Jensen CB, Madsbad S, Bjornholm M, Vaag A et al. Insulin signal transduction in skeletal muscle from glucose-intolerant relatives with type 2 diabetes. Diabetes 2001 50 2770-2778.

41 Burén J, Liu H-X, Jensen J \& Eriksson JW. Dexamethasone impairs insulin signalling and glucose transport by depletion of insulin receptor substrate-1, phosphatidylinositol 3-kinase and protein kinase B in primary cultured rat adipocytes. European Journal of Endocrinology 2002146 419-429.

42 Maier VH \& Gould GW. Long-term insulin treatment of 3T3-L1 adipocytes results in mis-targeting of GLUT4: implications for insulin-stimulated glucose transport. Diabetologia $2000 \mathbf{4 3}$ $1273-1281$.

43 Vannucci SJ, Nishimura H, Satoh S, Cushman SW, Holman GD \& Simpson IA. Cell surface accessibility of GLUT4 glucose transporters in insulin-stimulated rat adipose cells. Modulation by isoprenaline and adenosine. Biochemical Journal $1992 \mathbf{2 8 8} 325-330$.

44 Napoli R, Hirshman MF \& Horton ES. Mechanisms and time course of impaired skeletal muscle glucose transport activity in streptozotocin diabetic rats. Journal of Clinical Investigation 1995 $96427-437$.

45 Kahn BB, Charron MJ, Lodish HF, Cushman SW \& Flier JS. Differential regulation of two glucose transporters in adipose cells from diabetic and insulin-treated diabetic rats. Journal of Clinical Investigation $1989 \mathbf{8 4} 404-411$.

46 Garvey WT, Huecksteadt TP \& Birnbaum MJ. Pretranslational suppression of an insulin-responsive glucose transporter in rats with diabetes mellitus. Science 1989245 60-63.

47 Sun XJ, Goldberg JL, Qiao LY \& Mitchell JJ. Insulin-induced insulin receptor substrate-1 degradation is mediated by the proteasome degradation pathway. Diabetes 199948 1359-1364.

Received 4 July 2002

Accepted 16 October 2002 